ВИДОВОЙ СОСТАВ И РАСПРЕДЕЛЕНИЕ ПТИЦ В АЭРОПОРТУ НИЖНЕАНГАРСК И НА ПРИЛЕГАЮЩИХ ТЕРРИТОРИЯХ (БУРЯТИЯ) (c) 2020

\author{
Бадмаева Е.Н.', Доржиев Ц.3. ${ }^{1,2}$, Сергеев С.В. ${ }^{3}$, Гулгенов С.Ж. ${ }^{3}$, Максарова Д.Д. ${ }^{1}$ \\ 'Бурятский государственный университет им. Доржи Банзарова (г. Улан-Удэ, Российская Федерация) \\ ${ }^{2}$ Институт общей и экспериментальной биологии СО РАН (2. Улан-Удэ, Российская Федерация) \\ ${ }^{3}$ Восточно-Сибирский государственный университет технологий и управления
}

(2. Улан-Удэ, Российская Федерация)

\begin{abstract}
Аннотация. Проведено исследование видового состава птиц аэропорта Нижнеангарск (Северный Байкал, Бурятия) и прилегающих к нему территорий в радиусе 15 км. Большое разнообразие ландшафтов и биотопов обусловливает относительно богатое видовое и экологическое разнообразие птиц. Выявлено 145 видов, из них к отряду воробьеобразных относится 41,3\%, ржанкообразных - 19,2\%, гусеобразных - 11,7\% и соколообразных $-6,3 \%$, доля остальных отрядов небольшая (не более 4\%). По характеру пребывания преобладают перелетные гнездящиеся виды (64,8\%). В центральной зоне вокруг аэропорта в радиусе 2 км отмечено 39 видов птиц. Среди них обычными являются сизый голубь, свиристель, сорока, домовый и полевой воробьи. На прилегающих к аэропорту зоне (радиус 15 км) зарегистрировано 144 видов птиц. Самая большая концентрация водно-болотных видов птиц наблюдается в Верхнеангарском сору (заливе) оз. Байкал. Многочисленны здесь большой баклан, чайки, обычны утки. Среди птиц есть достаточно много видов, образующих крупные стаи и колонии, а также виды-воздухореи и парящие высоко над землей. Аэропорт Нижнеангарск в плане безопасности полетов воздушных судов расположен в зоне повышенного риска столкновения их с птицами. Это обстоятельство предусматривает усиления работы орнитологической службы данного аэропорта.

Ключевые слова: птицы; характер пребывания; численность; сезонная динамика фауны; воздушные суда; аэропорт Нижнеангарск; безопасность полетов; Бурятия.
\end{abstract}

\title{
SPECIES COMPOSITION AND DISTRIBUTION OF BIRDS IN NIZHNEANGARSK AIRPORT AND ADJACENT TERRITORIES (BURYATIA)
}

(C) 2020

\author{
Badmaeva E.N. ${ }^{1}$, Dorzhiev Ts.Z. ${ }^{1,2}$, Sergeev S.V. ${ }^{3}$, Gulgenov S.Zh. ${ }^{3}$, Maksarova D.D. ${ }^{1}$ \\ ${ }^{1}$ Buryat State University named after D. Banzarov (Ulan-Ude, Russian Federation) \\ ${ }^{2}$ Institute of General and Experimental Biology of the Siberian Branch of the Russian Academy of Sciences \\ (Ulan-Ude, Russian Federation) \\ ${ }^{3}$ East Siberia State University of Technology and Management (Ulan-Ude, Russian Federation)
}

Abstract. A study of the species composition of birds at the Nizhneangarsk airport (Northern Baikal, Buryatia) and the adjacent territories within a radius of $15 \mathrm{~km}$ was carried out. A wide variety of landscapes and biotopes determines a relatively rich species and ecological diversity of birds. 145 species were identified; the majority of them belong to the order of Passeriformes (41,3\%), Charadriiformes (19,2\%), Anseriformes (11,7\%) and Falconiformes $(6,3 \%)$, the share of other orders is small (no more than $4 \%$ ). 39 bird species were recorded in the central area around the airport within a $2 \mathrm{~km}$ radius. The rock dove, waxwing, magpie, house and field sparrows are common among them. 144 bird species have been recorded in the area adjacent to the airport (radius $15 \mathrm{~km}$ ). The largest concentration of wetland bird species is observed in the Verkhneangarsk sor (bay) of Lake Baikal. Cormorants, gulls and ducks are numerous here. Among the birds there are quite a few species that form large flocks and colonies, as well as species - feeding in the air and soaring high above the ground. Nizhneangarsk airport in terms of aircraft flight safety is located in an area of increased risk of collision with birds. This circumstance provides for strengthening the work of the ornithological service of this airport.

Keywords: birds; nature of stay; quantity; seasonal dynamics of fauna; aircraft; Nizhneangarsk airport; flight safety; Buryatia.

\section{Введение}

Проблема орнитологического обеспечения полетов воздушных судов остается актуальной во всем мире. В настоящее время в мире ежегодное число случаев столкновений воздушных судов с птицами превысило уже несколько тысяч. В России число столкновений тоже имеет тенденцию к росту, только в отдельных аэропортах, где функционируют полноценные орнитологические группы, положение несколько лучше. В гражданской авиации нашей стра- ны ежегодно происходит несколько десятков столкновений с птицами. Сталкиваются суда с различными по размерам и по виду птицами. Последствия этих столкновений бывают различными, порою они заканчиваются сильными разрушениями и повреждениями, имеются человеческие жертвы [1-11]. Поэтому в каждом аэропорту службы безопасности полетов обязаны иметь более или менее полную информацию о птицах на самом аэродроме и приаэродромной территории, т.е. владеть орнитологической 
обстановкой. В настоящее время во многих аэропортах проводятся орнитологические обследования [1217]. В Бурятии подобные работы начаты недавно [18-20]. Они предусматривают изучение и выявление видового состава и фактического нахождения птиц на определенной территории и в воздушном пространстве над ней в каком-либо отрезке времени, установление вероятности возникновения сложной орнитологической обстановки.

В настоящей работе приводятся результаты кратковременных исследований (это только начальный этап работы) орнитологической обстановки в гражданском аэропорту Нижнеангарск (Северо-Байкальский район, Республика Бурятия).

Цель данной работы: выявление эколого-орнитологической обстановки в районе гражданского аэропорта Нижнеангарск (Республика Бурятия) и прилегающей территории в радиусе 15 км.

\section{Материал и методика исследований}

Орнитологическая обстановка на аэродроме и приаэродромной территории гражданского аэропорта Нижнеангарск (Республика Бурятия) изучалась нами в течение 2020 г., а также в июне 1998-2001 гг.

Район исследования находится в Северном Прибайкалье в пос. Нижнеангарск у западного угла Ангарского сора оз. Байкал, близ устья реки Кичеры. На юго-западе посёлка, на въезде со стороны Северобайкальска, в Байкал впадает ручей Сырой Молокон. С северной и северо-западной стороны к поселку примыкают предгорья отрога хребта Сынныр, склоны которых покрыты темнохвойными лесами из сосны обыкновенной, лиственницы Гмелина, сосны сибирской, местами имеются участки еловых и пихтовых лесов с хорошо развитым подлеском, кустарниками и местами травянистым покровом, около поселка имеются полосы открытых участков.

На юго-восточной стороне пос. Нижнеангарска расположена уникальная водно-болотная экосистема - Верхне-Ангарский сор (залив). Он занимает территорию между устьевыми частями Кичеры и Верхней Ангары и отделен от Байкала островом Ярки и многочисленными мелкими островами. Кичера здесь образует дельту с протоками, старицами, озерами, болотами и лугами. Залив мелководный, хорошо прогревается (до $\left.+24^{\circ} \mathrm{C}\right)$, что способствует размножению и развитию водно-болотных растений и животных, часть которых заходит из Байкала.

Остров Ярки имеет вид узкой полосы длиной 11 км и шириной от 20 до 100 м. К востоку от о. Ярки тянется цепочка песчаных островов. Протяженность их вместе составляет более 17 км. В настоящее время вся эта экосистема взята под особую охрану Верхне-Ангарского государственного природного биологического заказника (создан в 1979 г.).

Верхнеангарский сор, о. Ярки, благодаря сочетанию различных условий, благоприятных для развития биоты, являются прекрасными местообитаниями для обитания (гнездования, питания, отдыха) многих видов водоплавающих, болотных и околоводных птиц. Не случайно здесь концентрируется огромное количество птиц.

С южной стороны пос. Нижнеангарск открываются воды Байкала. Для постоянного обитания птиц они не имеют большого значения, но многие водоплавающие и околоводные птицы во время перелетов с одного места в другое часто курсируют вдоль берега или отдыхают на берегу водоема. Прибрежные мелкие рачки и насекомые привлекают трясогузок, мелких куликов, служа им объектами питания.

Исследование птиц проведено нами на территории самого аэропорта, а также на прилегающих к нему территориях в радиусе 15 км. Для облегчения исследования предварительно вся территория была распределена нами на две зоны и каждая зона делилась на четыре сектора (рис. 1).

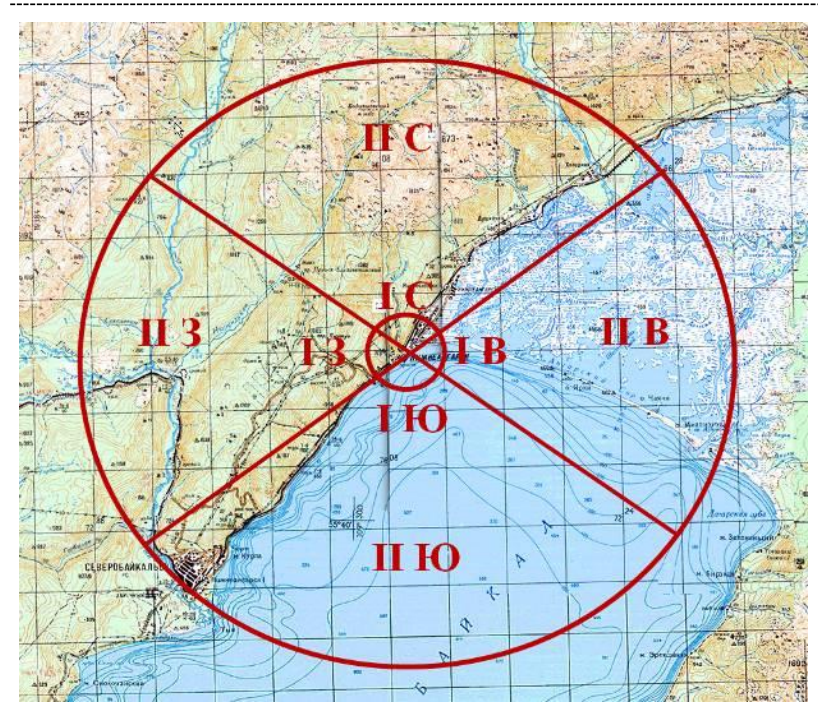

Рисунок 1 - Карта-схема пространственного зонирования района аэропорта Нижнеангарск и прилегающей территории.

Обозначения: $I$ - зона аэропорта;

II- зона прилегающей территории в радиусе 15 км; $C$ - северный сектор; $B$ - восточный сектор; Ю- южный сектор; 3- западный сектор

При рассмотрении экологических условий секторов сочли целесообразным объединить сектора IIЗ и IIC (западный и северный), поскольку они по соседству находятся в пределах лесного ландшафта. Лишь юго-западная часть IIC охватывает часть водной и прибрежной полос Верхнеангарского сора. К сектору IIB (восточный сектор) относится нижняя часть Верхнеангарского сора, о. Ярки с прилегающим водным пространством самого Байкала. Южный сектор (IIЮ) целиком находится в акватории Байкала и немного охватывает узкую прибрежную полосу вдоль Байкала до г. Северобайкальск.

Сектор IIЗ представляет собой предгорья крайне южного отрога хр. Сынныр, с которого стекает несколько горных речек, наиболее большая из них p. Сырой Молокон. Предгорья покрыты сосновым лесом, ближе к поселку появляются открытые участки. По экологическим условиям близок к нему сектор IIC. Здесь в небольших распадках встречаются участки темнохвойных лесов. В 6-8 км от поселка есть относительно крутые горы, на них местами получил развитие кедровый стланник. В этих двух секторах условия для обитания лесных и опушечных видов птиц нельзя оценивать как очень хорошие, они обусловлены преобладанием соснового леса, относи- 
тельно слабым развитием кустарникового и травяного покрова. Такие условия обеспечивают невысокую емкость угодий и не позволяют многим видам достигать высокой численности.

Южный сектор, где большую часть занимает открытая водная поверхность Байкала, для некоторых видов птиц (в основном чаек, реже водоплавающих птиц) может служить местом нерегулярного поиска корма или отдыха. Наземная узкая полоса и кустарники вдоль берега, дорога до г. Северобайкальска являются биотопом для небольшого числа околоводных и дендрофильно-кустарниковых видов птиц. Город Северобайкальск привлекает многих синантропных птиц.

Самой интересной и важной с точки зрения оценки орнитологической обстановки является сектор IIB - Верхнеангарский сор. Это идеальное место для обитания многих водно-болотных птиц в весеннелетне-осеннее время. С этого сектора птицы попадают на другие соседние участки, в том числе в район расположения аэропорта.

И наконец, зона I - зона самого аэропорта - с радиусом 2 км. Здесь также выделено четыре сектора. Поскольку территория аэропорта небольшая, можно дать общую характеристику. Одна часть зоны (сектора I3 и IC) наземная, где расположен пос. Нижнеангарск, включая аэропорт, а нижняя, юго-восточная часть зоны (сектора IЮ и IB) охватывает участок акватории Байкала. Территория пос. Нижнеангарск, примыкающая в аэропорту, занята жилыми и административными постройками, улицами. В целом имеются нормальные условия для обитания синантропных птиц. Акватория Байкала, как уже отмечали раньше, в основном служит для поиска корма и местом перемещений птиц с одного района в другой.

Авторами посещены практически все зоны с разной полнотой обследования, более тщательно изучены сектора, прилегающие к Верхнеангарскому сору, устьям рек Кичера и Верхняя Ангара, прилегающие районы акватории Байкала, поскольку здесь чаще концентрируются крупные птицы, потенциально опасные для воздушных судов. Относительно тщательно обследована территория самого аэродрома.

Методом точечного и маршрутного учета охвачены практически все зоны. Регистрировали всех встреченных видов, определяли их характер и сроки пребывания как в целом в регионе, так и в районе аэропорта. Балльная оценка численности видов проведена по общепринятой шкале А.П. Кузякина [21]. Названия и порядок расположения птиц даны по Е.А. Коблику, Я.А. Редькину и В.Ю. Архипову [22].

\section{Результаты исследований и их обсуждение}

\section{Таксономический состав птии}

В табл. 1 приводится список видов птиц аэропорта Нижнеангарск и прилегающих территорий в радиусе 15 км. Отмечено 145 видов птиц, относящихся к 16 отрядам. Это 33,6\% видового состава птиц Бурятии [23].

Подавляющее большинство видов относится к отряду воробьеобразных (41,3\%), затем идут ржанкообразные $(19,2 \%)$, гусеобразные $(11,7 \%)$ и соколо- образные $(6,3 \%)$, доля остальных отрядов небольшая (не более 4\%) (табл. 2). По характеру пребывания преобладают перелетные гнездящиеся виды $(64,8 \%)$, одну четвертую часть составляют оседлые $(26,2 \%)$, чуть менее десятой части - пролетные $(8,3 \%)$.

\section{Распределение птиц в зонах аэропорта}

и прилегающих территорий

В зоне I аэропорта, который имеет радиус примерно 2 км, обнаружено 39 видов птиц (табл. 1). Из них всего 13 видов отмечено в зимнее время. Среди них обычными являются сизый голубь, свиристель, сорока, домовый и полевой воробьи, остальные редки и очень редки. Свиристели держатся здесь эпизодически, поздней осенью стаи, насчитывающие иногда до 200-300 особей, могут появляться на рябинах, черемухах в близлежащих к аэропорту участках частного сектора. Обычно за 10-15 дней они полностью объедают ягоды с этих растений и исчезают из этих мест. Сороки зимой по одной или 3-4 птицы постоянно посещают зону аэропорта. Здесь же всегда можно увидеть сизых голубей, домовых и полевых воробьев. Большей частью они обитают на участках частного жилого сектора.

С наступлением весны, с первой декады апреля до конца мая, идет пролет и прилет птиц из районов зимовки. В теплое время в зоне I зарегистрировано 38 видов, из зимней фауны поселок покинула только свиристель. Постоянных обитателей здесь мало, среди них обычны сизый голубь, белопоясный стриж, деревенская ласточка, воронок, белая трясогузка, сибирская горихвостка, каменка и воробьи. Из соседних природных биотопов сюда часто залетают чайки. Другие виды редки.

На прилегающей к аэропорту территории (зона II) отмечено все 145 видов птиц (табл. 1). Некоторые из них встречаются только весной и осенью в период пролета (в основном кулики, малый лебедь, гуменник). С точки зрения безопасности полетов воздушных судов большой интерес представляет сектор IIB, представляющий собой водно-болотное угодье Верхнеангарского сора (залива) оз. Байкал, где концентрируется огромное количество птиц. Здесь многочисленными являются большой баклан, чайки (сизая, монгольская, озерная), красноголовый и хохлатый чернети. Обычны многие виды уток, лысуха, речная крачка, чибис и т.д. Колонии чаек, крачек расположены во многих местах Верхнеангарского сора. По годам численность их в зависимости от уровня воды меняется [24]. На болотах и лугах гнездятся многие виды куликов, а о. Ярки привлекает как наземных, так и околоводных птиц. Большое количество разных видов птиц привлекает многих хищных птиц, которые здесь находят хорошую кормовую базу.

Из сектора IIB птицы посещают соседние территории, в том числе пос. Ангарск. Синатропные виды отмечаются в крайней северо-западной точке сектора IIЮ в г. Северобайкальск, который расположен на берегу Байкала в 14 км от пос. Нижнеангарск. В наземных секторах (II3 и IIC) численность птиц относительно низкая (представители куриных, воробьеобразных и др.). 
Таблица 1 - Видовой состав, характер пребывания и численность птиц аэропорта Нижнеангарск и прилегающей территории в радиусе 15 км в весенне-летне-осенний период

\begin{tabular}{|c|c|c|c|c|c|c|c|c|c|c|}
\hline \multirow{3}{*}{ № } & \multirow{3}{*}{ Отряды и виды птиц } & \multirow{3}{*}{$\begin{array}{l}\text { Харак- } \\
\text { тер } \\
\text { пребы- } \\
\text { вания }\end{array}$} & \multicolumn{8}{|c|}{ Численность птиц в разных зонах и секторах } \\
\hline & & & \multicolumn{4}{|c|}{$\begin{array}{c}\text { Зона аэродрома } \\
(\mathrm{R}=2 \mathrm{\kappa M})\end{array}$} & \multicolumn{4}{|c|}{$\begin{array}{l}\text { Зона, прилегающая к аэ- } \\
\text { родрому }(\mathrm{R}=2,0-15 \text { км }\end{array}$} \\
\hline & & & $\mathrm{C}$ & $\mathrm{B}$ & Ю & 3 & $\mathrm{C}^{*}$ & $\mathrm{~B}$ & Ю & 3 \\
\hline \multicolumn{11}{|c|}{ Отряд Курообразные Galliformes } \\
\hline 1 & Рябчик Tetrastes bonasia & $\mathrm{Oc}$ & - & - & - & - & + & - & - & + \\
\hline 2 & Каменный глухарь Tetrao parvirostris & $\mathrm{Oc}$ & - & - & - & - & + & - & - & - \\
\hline 3 & Немой перепел Coturnix japonica & $\Gamma \mathrm{H}$ & - & - & - & - & - & + & - & - \\
\hline \multicolumn{11}{|c|}{ Отряд Гусеобразные Anseriformes } \\
\hline 4 & Лебедь-кликун Cygnus cygnus & $\Gamma \mathrm{H}$ & - & - & - & - & - & + & $(+)$ & - \\
\hline 5 & Малый лебедь Cygnus bewickii & $\Pi p$ & - & - & - & - & - & ++ & - & - \\
\hline 6 & Гуменник Anser fabalis & $\Pi p$ & - & - & - & - & - & +++ & + & - \\
\hline 7 & Свиязь Anas penelope & $\Gamma \mathrm{H}$ & - & - & - & - & & ++ & $(+)$ & - \\
\hline 8 & Серая утка Anas strepera & $\Gamma \mathrm{H}$ & - & - & - & - & & + & - & - \\
\hline 9 & Чирок-свистунок Anas crecca & $\Gamma \mathrm{H}$ & - & $(+)$ & $(+)$ & - & & ++ & $(+)$ & - \\
\hline 10 & Кряква Anas platyrhynchos & $\Gamma \mathrm{H}$ & - & $(+)$ & $(+)$ & - & - & ++ & + & - \\
\hline 11 & Шилохвость Anas acuta & $\Gamma \mathrm{H}$ & - & - & - & - & & ++ & + & - \\
\hline 12 & Чирок-трескунок Anas querquedula & $\Gamma_{\mathrm{H}}$ & - & - & - & - & & ++ & + & - \\
\hline 13 & Широконоска Anas clypeata & $\Gamma \mathrm{H}$ & - & - & - & - & & ++ & - & - \\
\hline 14 & Красноголовый нырок Aythya ferina & $\Gamma_{\mathrm{H}}$ & - & - & - & - & & +++ & $(+)$ & - \\
\hline 15 & Хохлатая чернеть Aythya fuligula & $\Gamma \mathrm{H}$ & - & - & - & - & & +++ & + & - \\
\hline 16 & Горбоносый турпан Melanitta deglandi & $\Gamma \mathrm{H}$ & & & & & & + & - & - \\
\hline 17 & Гоголь Bucephala clangula & $\Gamma \mathrm{H}$ & - & - & - & - & & ++ & + & - \\
\hline 18 & Луток Mergus albellus & $\Gamma \mathrm{H}$ & & & & & & + & - & - \\
\hline 19 & Длинноносый крохаль Mergus serrator & $\Gamma \mathrm{H}$ & - & - & - & - & & + & + & - \\
\hline 20 & Большой крохаль Mergus merganser & $\Gamma \mathrm{H}$ & - & - & - & - & & + & + & - \\
\hline
\end{tabular}

19 Длинноносый крохаль Mergus serrator

Отряд Пеликанообразные Pelecaniformes

\begin{tabular}{l|l|c|c|c|c|c|c|c|c|c|}
21 & Большой баклан Phalacrocorax carbo & Гн & - & - & + & + & - & +++ & +++ & - \\
\hline
\end{tabular} Отряд Аистообразные Ciconiiformes

\begin{tabular}{|c|l|c|c|c|c|c|c|c|c|c|}
\hline 22 & Большая выпь Botaurus stellaris & Гн & - & - & - & - & - & $(+)$ & - & - \\
\hline 23 & Серая цапля Ardea cinerea & Гн & & & & & & ++ & $(+)$ & - \\
\hline 24 & Черный аист Ciconia nigra & $\Gamma_{\mathrm{H}}$ & - & - & - & - & - & $(+)$ & - & - \\
\hline
\end{tabular}

24 Черный аист Ciconia nigra

\begin{tabular}{|c|l|c|c|c|c|c|c|c|c|c|}
\hline 25 & Чомга Podiceps cristatus & $\Gamma_{\mathrm{H}}$ & - & - & - & - & - & + & $(+)$ & - \\
\hline 26 & Черношейная поганка Podiceps nigricollis & $\Gamma_{\mathrm{H}}$ & - & - & - & - & - & + & - & - \\
\hline 27 & Красношейная поганка Podiceps auritus & $\Gamma_{\mathrm{H}}$ & - & - & - & - & - & $(+)$ & - & - \\
\hline
\end{tabular}

27 Красношейная поганка Podiceps auritus

Отряд Соколообразные Falconiformes

\begin{tabular}{|c|l|c|c|c|c|c|c|c|c|c|}
\hline 28 & Пустельга Falco tinnunculus & $\Gamma_{\mathrm{H}}$ & + & - & - & + & + & $(+)$ & - & + \\
\hline 29 & Скопа Pandion haliaetus & $\Gamma_{\mathrm{H}}$ & - & - & - & - & - & $(+)$ & $(+)$ & - \\
\hline 30 & Черный коршун Milvus migrans & $\Gamma_{\mathrm{H}}$ & + & + & + & + & + & + & + & + \\
\hline 31 & Орлан-белохвост Haliaeetus albicilla & $\Gamma_{\mathrm{H}}$ & - & - & $(+)$ & - & - & $(+)$ & $(+)$ & - \\
\hline 32 & Восточный лунь Circus spilonotus & $\Gamma_{\mathrm{H}}$ & - & - & - & - & - & ++ & + & - \\
\hline 33 & Перепелятник Accipiter nisus & $\Gamma_{\mathrm{H}}$ & $(+)$ & - & - & - & + & - & - & + \\
\hline 34 & Тетеревятник Accipiter gentilis & Ос & - & - & - & - & $(+)$ & - & - & $(+)$ \\
\hline 35 & Канюк Buteo buteo & $\Gamma_{\mathrm{H}}$ & - & - & - & - & $(+)$ & - & - & $(+)$ \\
\hline 36 & Беркут Aquila chrysaetos & Ос & - & - & - & - & $(+)$ & - & - & $(+)$ \\
\hline
\end{tabular}

36 Беркут Aquila chrysaetos

Отряд Журавлеобразные Gruiformes

\begin{tabular}{|l|l|c|c|c|c|c|c|c|c|c|}
37 & Серый журавль Grus grus & Гн & - & - & - & - & - & + & - & - \\
38 & Лысуха Fulica atra & Гн & - & - & - & - & - & +++ & $(+)$ & - \\
\hline
\end{tabular}

38 Лысуха Fulica atra

\begin{tabular}{|r|l|c|c|c|c|c|c|c|c|c|}
\hline 39 & Чибис Vanellus vanellus & $\Gamma_{\mathrm{H}}$ & - & - & - & - & - & ++ & - & - \\
\hline 40 & Малый зуек Charadrius dubius & $\Gamma_{\mathrm{H}}$ & - & - & $(+)$ & - & - & + & + & - \\
\hline 41 & Вальдшнеп Scolopax rusticola & $\Gamma_{\mathrm{H}}$ & - & - & - & - & - & - & - & $(+)$ \\
\hline 42 & Азиатский бекас Gallinago stenura & $\Gamma_{\mathrm{H}}$ & - & - & - & - & - & + & - & - \\
\hline 43 & Бекас Gallinago gallinago & $\Gamma_{\mathrm{H}}$ & - & - & - & - & - & + & - & - \\
\hline 44 & Большой кроншнеп Numenius arquata & $\Gamma_{\mathrm{H}}$ & - & - & - & $(+)$ & - & + & - & - \\
\hline 45 & $\begin{array}{l}\text { Др, зал } \\
\text { Дальневосточный кроншнеп }\end{array}$ & - & - & - & - & - & $(+)$ & - & - \\
\hline 46 & Мегольи таdagascariensis & Пр & - & - & - & - & - & ++ & - & - \\
\hline \hline
\end{tabular}




\begin{tabular}{|c|c|c|c|c|c|c|c|c|c|c|}
\hline \multirow{3}{*}{ № } & \multirow{3}{*}{ Отряды и виды птиц } & \multirow{3}{*}{$\begin{array}{l}\text { Харак- } \\
\text { тер } \\
\text { пребы- } \\
\text { вания }\end{array}$} & \multicolumn{8}{|c|}{ Численность птиц в разных зонах и секторах } \\
\hline & & & \multicolumn{4}{|c|}{$\begin{array}{c}\text { Зона аэродрома } \\
(\mathrm{R}=2 \text { км }) \\
\end{array}$} & \multicolumn{4}{|c|}{$\begin{array}{l}\text { Зона, прилегающая к аэ- } \\
\text { родрому }(\mathrm{R}=2,0-15 \text { км })\end{array}$} \\
\hline & & & $\mathrm{C}$ & $\mathrm{B}$ & Ю & 3 & $\mathrm{C}^{*}$ & $\mathrm{~B}$ & Ю & 3 \\
\hline 47 & Травник Tringa totanus & $\Gamma_{\mathrm{H}}$ & - & - & - & - & - & + & - & - \\
\hline 48 & Поручейник Tringa stagnatilis & $\Gamma \mathrm{H}$ & - & - & - & - & - & + & - & - \\
\hline 49 & Большой улит Tringa nebularia & $\Gamma \mathrm{H}$ & - & - & - & - & - & + & - & - \\
\hline 50 & Черныш Tringa ochropus & $\Gamma \mathrm{H}$ & - & - & - & - & - & + & - & - \\
\hline 51 & Фифи Tringa glareola & $\Gamma_{\mathrm{H}}$ & - & - & - & - & - & + & - & - \\
\hline 52 & $\begin{array}{l}\text { Сибирский пепельный улит } \\
\text { Heteroscelus brevipes }\end{array}$ & Пр & - & - & - & - & - & + & - & - \\
\hline 53 & Перевозчик Actitis hypoleucos & $\Gamma \mathrm{H}$ & + & - & - & + & - & + & + & - \\
\hline 54 & Кулик-воробей Calidris minuta & $\Pi p$ & - & - & - & - & - & + & - & - \\
\hline 55 & Длиннопалый песочник Calidris subminuta & $\Pi p$ & - & - & - & - & - & $(+)$ & - & - \\
\hline 56 & Белохвостый песочник Calidris temminckii & $\Pi p$ & - & - & - & - & - & + & - & - \\
\hline 57 & Краснозобик Calidris ferruginea & $\Pi p$ & - & - & - & - & - & $(+)$ & - & - \\
\hline 58 & Чернозобик Calidris alpina & $\Pi p$ & - & - & - & - & - & $(+)$ & - & - \\
\hline 59 & Турухтан Phylomachus pugnax & $\Gamma \mathrm{H}$ & - & - & - & - & - & ++ & - & - \\
\hline 60 & Сизая чайка Larus canus & $\Gamma \mathrm{H}$ & ++ & ++ & ++ & ++ & + & ++++ & +++ & + \\
\hline 61 & Монгольская чайка Larus mongolicus & $\Gamma \mathrm{H}$ & ++ & ++ & ++ & ++ & + & ++++ & +++ & + \\
\hline 62 & Озерная чайка Larus ridibundus & $\Gamma \mathrm{H}$ & ++ & + & + & ++ & - & +++ & ++ & - \\
\hline 63 & Малая чайка Larus minutus & $\Gamma \mathrm{H}$ & $(+)$ & $(+)$ & $(+)$ & $(+)$ & - & + & + & - \\
\hline 64 & Чеграва Hydroprogne caspia & $\Gamma \mathrm{H}$ & - & - & - & - & - & + & $(+)$ & - \\
\hline 65 & Речная крачка Sterna hirundo & $\Gamma \mathrm{H}$ & & + & + & $(+)$ & - & ++ & ++ & - \\
\hline 66 & Белокрылая крачка Chlidonias leucopterus & $\Gamma \mathrm{H}$ & - & - & - & - & - & + & - & - \\
\hline \multicolumn{11}{|c|}{ Отряд Голубеобразные Columbiformes } \\
\hline 67 & Сизый голубь Columba livia & Oc & ++ & - & ++ & - & - & - & ++ & - \\
\hline 68 & Скальный голубь Columba rupestris & $\mathrm{Oc}$ & + & - & + & - & - & - & + & - \\
\hline 69 & Большая горлица Streptopelia orientalis & $\Gamma \mathrm{H}$ & - & - & - & - & $(+)$ & - & - & ++ \\
\hline \multicolumn{11}{|c|}{ Отряд Кукушкообразные Cuculiformes } \\
\hline 70 & Кукушка Cuculus canorus & $\Gamma \mathrm{H}$ & - & - & - & - & ++ & - & $(+)$ & ++ \\
\hline 71 & Глухая кукушка Cuculus optatus & $\Gamma_{\mathrm{H}}$ & - & - & - & - & + & - & - & + \\
\hline \multicolumn{11}{|c|}{ Отряд Совообразные Strigiformes } \\
\hline 72 & Длиннохвостая неясыть Strix uralensis & Oc & - & - & - & - & $(+)$ & - & - & $(+)$ \\
\hline 73 & Бородатая неясыть Strix nebulosa & Oc & - & - & - & - & $(+)$ & - & - & $(+)$ \\
\hline 74 & Ушастая сова Asio otus & $\mathrm{Oc}$ & - & - & - & - & $(+)$ & $(+)$ & - & - \\
\hline 75 & Болотная сова Asio flammeus & Oc & - & - & - & - & - & $(+)$ & - & - \\
\hline \multicolumn{11}{|c|}{ Отряд Козодоеобразные Caprimulgiformes } \\
\hline 76 & Козодой Caprimulgus europaeus & $\Gamma_{\mathrm{H}}$ & - & - & - & - & $(+)$ & - & - & $(+)$ \\
\hline \multicolumn{11}{|c|}{ Отряд Стрижеобразные Apodiformes } \\
\hline 77 & Колючехвостый стриж Hyrundapus caudacutus & $\Gamma_{\mathrm{H}}$ & - & - & - & - & - & - & - & $(+)$ \\
\hline 78 & Черный стриж Apus apus & $\Gamma \mathrm{H}$ & & & & & $(+)$ & & & $(+)$ \\
\hline 79 & Белопоясный стриж Apus pacificus & $\Gamma \mathrm{H}$ & ++ & - & - & ++ & - & - & ++++ & - \\
\hline \multicolumn{11}{|c|}{ Отряд Птицы-носороги Bucerotiformes } \\
\hline 80 & Удод Uрира ерорs & $\Gamma_{\mathrm{H}}$ & + & - & - & + & - & - & + & - \\
\hline \multicolumn{11}{|c|}{ Отряд Дятлообразные Piciformes } \\
\hline 81 & Белоспинный дятел Dendrocopos leucotos & $\mathrm{Oc}$ & - & - & - & - & + & - & - & + \\
\hline 82 & Большой пестрый дятел Dendrocopos major & $\mathrm{Oc}$ & - & - & - & - & ++ & - & + & ++ \\
\hline 83 & Трехпалый дятел Picoides tridactylus & $\mathrm{Oc}$ & - & - & - & - & - & - & - & $(+)$ \\
\hline 84 & Желна Dryocopus martius & $\mathrm{Oc}$ & - & - & - & - & + & - & - & + \\
\hline 85 & Седой дятел Picus canus & Oc & - & - & - & - & - & - & - & $(+)$ \\
\hline \multicolumn{11}{|c|}{ Отряд Воробьеобразные Passeriformes } \\
\hline 86 & Полевой жаворонок Alauda arvensis & $\Gamma_{\mathrm{H}}$ & - & - & - & - & - & + & - & - \\
\hline 87 & Деревенская ласточка Hirundo rustica & $\Gamma \mathrm{H}$ & ++ & - & - & ++ & - & + & + & - \\
\hline 88 & Воронок Delichon urbicum & $\Gamma \mathrm{H}$ & +++ & - & - & +++ & - & - & + & - \\
\hline 89 & Степной конек Anthus richardi & $\Gamma_{\mathrm{H}}$ & - & - & - & - & - & + & - & - \\
\hline 90 & Пятнистый конек Anthus hodgsoni & $\Gamma \mathrm{H}$ & - & - & - & - & ++ & - & + & ++ \\
\hline 91 & Желтоголовая трясогузка Motacilla citreola & $\Gamma \mathrm{H}$ & $(+)$ & - & - & - & - & ++ & - & - \\
\hline 92 & Горная трясогузка Motacilla cinerea & $\Gamma \mathrm{H}$ & + & - & - & $(+)$ & + & + & + & + \\
\hline 93 & Белая трясогузка Motacilla alba & $\Gamma \mathrm{H}$ & ++ & - & - & ++ & - & + & ++ & - \\
\hline 94 & Свиристель Bombicilla garrulus & $\mathrm{Oc}$ & ++ & - & - & ++ & - & - & - & $(+)$ \\
\hline 95 & Краснозобый дрозд Turdus ruficollis & $\Gamma \mathrm{H}$ & - & - & - & - & $(+)$ & - & - & $(+)$ \\
\hline
\end{tabular}




\begin{tabular}{|c|c|c|c|c|c|c|c|c|c|c|}
\hline \multirow{3}{*}{ № } & \multirow{3}{*}{ Отряды и виды птиц } & \multirow{3}{*}{$\begin{array}{c}\text { Харак- } \\
\text { тер } \\
\text { пребы- } \\
\text { вания }\end{array}$} & \multicolumn{8}{|c|}{ Численность птиц в разных зонах и секторах } \\
\hline & & & \multicolumn{4}{|c|}{$\begin{array}{c}\text { Зона аэродрома } \\
\quad(\mathrm{R}=2 \mathrm{\kappa M})\end{array}$} & \multicolumn{4}{|c|}{$\begin{array}{l}\text { Зона, прилегающая к аэ- } \\
\text { родрому }(\mathrm{R}=2,0-15 \text { км })\end{array}$} \\
\hline & & & $\mathrm{C}$ & $\mathrm{B}$ & Ю & 3 & $\mathrm{C}^{*}$ & $\mathrm{~B}$ & Ю & 3 \\
\hline 96 & Бурый дрозд Turdus eunomus & $\Gamma_{\mathrm{H}}$ & - & - & - & - & $(+)$ & - & - & - \\
\hline 97 & Пестрый дрозд Zoothera varia & $\Gamma_{\mathrm{H}}$ & - & - & - & - & $(+)$ & - & - & - \\
\hline 98 & Сибирская горихвостка Phoenicurus auroreus & $\Gamma \mathrm{H}$ & ++ & - & - & ++ & + & + & + & + \\
\hline 99 & Соловей-свистун Luscinia sibilans & $\Gamma_{\mathrm{H}}$ & - & - & - & - & - & - & - & + \\
\hline 100 & Синий соловей Luscinia cyane & $\Gamma_{\mathrm{H}}$ & - & - & - & - & $(+)$ & - & - & $(+)$ \\
\hline 101 & Соловей-красношейка Luscinia calliope & $\Gamma \mathrm{H}$ & - & - & - & - & + & ++ & $(+)$ & + \\
\hline 102 & $\begin{array}{l}\text { Восточный черноголовый чекан } \\
\text { Saxicola stejnegeri }\end{array}$ & $\Gamma_{\mathrm{H}}$ & - & - & - & - & - & ++ & - & - \\
\hline 103 & Каменка Oenanthe oenanthe & $\Gamma \mathrm{H}$ & ++ & - & - & ++ & - & + & ++ & - \\
\hline 104 & Сибирская мухоловка Muscicapa sibirica & $\Gamma_{\mathrm{H}}$ & - & - & - & - & + & - & - & + \\
\hline 105 & $\begin{array}{l}\text { Ширококлювая мухоловка } \\
\text { Muscicapa dauurica }\end{array}$ & $\Gamma_{\mathrm{H}}$ & - & - & - & - & + & - & - & + \\
\hline 106 & Таежная мухоловка Ficedula mugimaki & $\Gamma \mathrm{H}$ & - & - & - & - & $(+)$ & - & - & - \\
\hline 107 & $\begin{array}{l}\text { Восточная малая мухоловка } \\
\text { Ficedula albicilla }\end{array}$ & $\Gamma_{\mathrm{H}}$ & - & - & - & - & + & $(+)$ & - & ++ \\
\hline 108 & Пятнистый сверчок Locustella lanceolata & $\Gamma_{\mathrm{H}}$ & - & - & - & - & - & + & - & - \\
\hline 109 & Зеленая пеночка Phylloscopus trochiloides & $\Gamma \mathrm{H}$ & - & - & - & - & + & - & - & + \\
\hline 110 & Пеночка-зарничка Phylloscopus inornatus & $\Gamma_{\mathrm{H}}$ & - & - & - & - & - & - & - & + \\
\hline 111 & Корольковая пеночка Phylloscopus proregulus & $\Gamma_{\mathrm{H}}$ & - & - & - & - & + & - & - & ++ \\
\hline 112 & Бурая пеночка Phylloscopus fuscatus & $\Gamma \mathrm{H}$ & - & - & - & - & + & ++ & - & + \\
\hline 113 & Славка-мельничек Sylvia curruca & $\Gamma \mathrm{H}$ & - & - & - & - & + & ++ & + & + \\
\hline 114 & Пухляк Parus montanus & Oc & - & - & - & - & +++ & - & - & +++ \\
\hline 115 & Московка Parus ater & $\mathrm{Oc}$ & - & - & - & - & + & - & - & ++ \\
\hline 116 & Большая синица Parus major & $\mathrm{Oc}$ & + & - & - & + & ++ & + & + & ++ \\
\hline 117 & Поползень Sitta europaea & $\mathrm{Oc}$ & - & - & - & - & ++ & - & - & ++ \\
\hline 118 & Сибирский жулан Lanius cristatus & $\Gamma \mathrm{H}$ & - & - & - & - & $(+)$ & ++ & - & + \\
\hline 119 & Кукша Perisoreus infaustus & $\mathrm{Oc}$ & - & - & - & - & $(+)$ & - & - & + \\
\hline 120 & Сойка Garrulus glandarius & $\mathrm{Oc}$ & - & - & - & - & + & - & - & ++ \\
\hline 121 & Голубая сорока Cyanopica cyanus & $\mathrm{Oc}$ & - & - & - & - & + & +++ & - & + \\
\hline 122 & Сорока Pica pica & $\mathrm{Oc}$ & + & - & - & + & + & ++ & ++ & + \\
\hline 123 & Кедровка Nucifraga caryocatactes & Oc & - & - & - & - & + & - & - & ++ \\
\hline 124 & Восточная черная ворона Corvus orientalis & $\mathrm{Oc}$ & + & - & - & + & + & ++ & + & + \\
\hline 125 & Bopoн Corvus corax & $\mathrm{Oc}$ & $(+)$ & - & - & $(+)$ & + & + & + & ++ \\
\hline 126 & Скворец Sturnus vulgaris & $\Gamma_{\mathrm{H}}$ & + & - & - & $(+)$ & - & - & + & - \\
\hline 127 & Домовый воробей Passer domesticus & $\mathrm{Oc}$ & ++ & - & - & ++ & - & - & ++ & - \\
\hline 128 & Полевой воробей Passer montanus & $\mathrm{Oc}$ & ++ & - & - & ++ & - & ++ & ++ & - \\
\hline 129 & Юрок Fringilla montifringilla & Oc & - & - & - & - & + & - & - & ++ \\
\hline 130 & Чиж Spinus spinus & Oc & - & - & - & - & + & - & - & + \\
\hline 131 & Чечетка Acanthis flammea & Зим & - & - & - & - & +++ & + & - & +++ \\
\hline 132 & Урагус Uragus sibiricus & Oc & $(+)$ & - & - & - & - & + & + & - \\
\hline 133 & Чечевица Carpodacus erytrinus & $\mathrm{Oc}$ & $(+)$ & - & - & $(+)$ & + & ++ & + & + \\
\hline 134 & Клест-еловик Loxia curvirostra & $\mathrm{Oc}$ & - & - & - & - & + & - & - & ++ \\
\hline 135 & Белокрылый клест Loxia leucoptera & Oc & - & - & - & - & ++ & - & - & ++ \\
\hline 136 & Снегирь Pyrrhula pyrrhula & $\mathrm{Oc}$ & $(+)$ & - & - & $(+)$ & + & - & - & + \\
\hline 137 & Серый снегирь Pyrrhula cineracea & $\mathrm{Oc}$ & $(+)$ & - & - & $(+)$ & + & - & - & + \\
\hline 138 & Дубонос Coccothraustes coccothraustes & $\mathrm{Oc}$ & - & - & - & - & + & - & - & + \\
\hline 139 & Белошапочная овсянка Emberiza leucocephala & $\Gamma \mathrm{H}$ & $(+)$ & - & - & - & +++ & $(+)$ & + & ++ \\
\hline 140 & Камышовая овсянка Schoeniclus schoeniclus & $\Gamma \mathrm{H}$ & - & - & - & - & - & ++ & - & - \\
\hline 141 & Полярная овсянка Schoeniclus pallasi & $\Gamma \mathrm{H}$ & - & - & - & - & - & + & - & - \\
\hline 142 & Дубровник Ocyris aureolus & $\Gamma \mathrm{H}$ & - & - & - & - & - & $(+)$ & - & - \\
\hline 143 & Седоголовая овсянка Ocyris spodocephalus & $\Gamma \mathrm{H}$ & - & - & - & - & + & ++ & + & + \\
\hline 144 & Овсянка-крошка Ocyris pusillus & $\Pi p$ & - & - & - & - & - & ++ & - & - \\
\hline 145 & Овсянка-ремез Ocyris rusticus & $\Pi p$ & - & - & - & - & + & - & - & + \\
\hline
\end{tabular}

Примечания. Характеры пребывания птиц: $O$ - оседлый; $\Gamma$ - перелетный гнездящийся; зим - зимующий; $\Pi p$ - пролетный. Зоны: $I$ - зона аэродрома; II - зона территории, прилегающей к аэродрому в радиусе 15 км. Секторы: $C^{*}$ - северный (птицы южной части сектора, охватывающую водно-болотные местообитания отнесены к сектору В); $B$ - восточный; $Ю$ - южный; 3 - западный. Численность: ++++ - очень многочисленный; +++ - многочисленный; ++ - обычный; + - редкий; $(+)$ - очень редкий. 
Таблица 2 - Соотношение видов разных отрядов и экологических групп птиц по характеру пребывания в аэропорту Нижнеангарск и прилегающих к нему территориях в радиусе 15 км

\begin{tabular}{|c|c|c|c|c|c|c|}
\hline \multirow{2}{*}{ Отряды } & \multicolumn{2}{|c|}{ Количество видов } & \multicolumn{4}{|c|}{ из них по характеру пребывания, видов } \\
\hline & абс. & отн., \% & оседлые & перелетные гнездящиеся & пролетные & зимующие \\
\hline Galliformes & 3 & 2,1 & 2 & 1 & - & - \\
\hline Anseriformes & 17 & 11,7 & - & 15 & 2 & - \\
\hline Pelecaniformes & 1 & 0,7 & - & 1 & - & - \\
\hline Ciconiiformes & 3 & 2,1 & - & 3 & - & - \\
\hline Podicipediformes & 3 & 2,1 & - & 3 & - & - \\
\hline Falconiformes & 9 & 6,2 & 2 & 7 & - & - \\
\hline Gruiformes & 2 & 1,4 & - & 2 & - & - \\
\hline Charadriiformes & 28 & 19,2 & - & 20 & 8 & - \\
\hline Columbiformes & 3 & 2,1 & 2 & 1 & - & - \\
\hline Cuculiformes & 2 & 1,4 & - & 2 & - & - \\
\hline Strigiformes & 4 & 2,8 & 4 & - & - & - \\
\hline Caprimulgiformes & 1 & 0,7 & - & 1 & - & - \\
\hline Apodiformes & 3 & 2,1 & - & 3 & - & - \\
\hline Bucerotiformes & 1 & 0,7 & - & 1 & - & - \\
\hline Piciformes & 5 & 3,4 & 5 & - & - & - \\
\hline Passeriformes & 60 & 41,3 & 23 & 34 & 2 & 1 \\
\hline Всего: & 145 & 100 & $38(26,2 \%)$ & $94(64,8 \%)$ & $12(8,3 \%)$ & $1(0,7 \%)$ \\
\hline
\end{tabular}

\section{Заключение}

Гражданский аэропорт Нижнеангарск в плане безопасности полетов воздушных судов расположен в зоне повышенного риска столкновения их с птицами. Вблизи аэропорта находится уникальное водно-болотное угодье Верхнеангарский сор оз. Байкал, представляющее собой место повышенной концентрации многих видов водно-болотных и околоводных птиц для гнездовья или отдыха в период пролета.

Разнообразие ландшафтов и наземных, водноболотных и селитебных местообитаний птиц на территории вокруг аэропорта обусловливает относительно богатое видовое и экологическое разнообразие птиц.

Среди них есть достаточно много видов, образующих крупные стаи и колонии, а также виды-воздухореи и парящие высоко над землей. Это обстоятельство предусматривает усиление работы орнитологической службы данного аэропорта.

\section{Список литературы:}

1. Якоби В.Э. Биологические основы предотвращения столкновения самолетов с птицами. М.: Наука, 1974. $166 \mathrm{c}$.

2. Ильичев В.Д., Бирюков В.Я., Нечваль Н.А. Технико-экологическая стратегия защиты от биоповреждений (Серия «Биологические повреждения»). М.: Наука, 1995. $248 \mathrm{c}$.

3. Ильичев В.Д., Силаева О.Л., Козлов Ю.П. Системные подходы в аэродромной экологии // Вестник РУДН. Серия Экология и безопасность жизнедеятельности. 2006. № 1 (13). С. 124-127.

4. Ильичев В.Д., Силаева О.Л., Золотарёв С.С. Поведением птиц управляет... компьютер // Наука в России. 2006. № 4. С. 24-28.

5. Грабовский М.А. Пернатые хищники и авиация // Пернатые хищники и их охрана. 2008. № 12. С. 7-10.

6. Силаева О.Л., Ильичёв В.Д., Золотарёв С.С. Основные направления авиационной орнитологии // Вест- ник РУДН. Серия Экология и безопасность жизнедеятельности. 2010. № 5. С. 10-14.

7. Колесниченко Ю.М. Орнитологическая безопасность полетов: проблемы и пути решения // Проблемы безопасности полетов. М.: ВИНИТИ, 2012. № 12. С. 2634.

8. Рыжов С.К. Столкновения с птицами. Актуальные аспекты // Труды общества независимых расследователей авиационных происшествий. М., 2013. Вып. 25. C. $175-179$.

9. Кучински М.Г. Мероприятия по уменьшению орнитологической опасности в аэропорту // Вестник РУДН. Серия «Экология и безопасность жизнедеятельности». 2015. № 2. С. 75-84.

10. Мацюра А.В. Радиолокационные орнитологические наблюдения: краткий обзор стационарных и мобильных комплексов // Acta Biologica Sibirica. 2015. № 1 (3-4). C. 118-147. DOI: 10.14258/abs.v1i3-4.917.

11. Якоби В.Э. Миграции, ночные полёты и залёты чёрных стрижей Apus apus (по данным анализа столкновений с самолётами) // Русский орнитологический журнал. 2019. Т. 28, экспресс-выпуск 1805. С. 3676-3678.

12. Зацаринный И.В., Шаврина У.Ю., Большаков А.А. Птицы аэродрома Хибины (Мурманская область) // Русский орнитологический журнал. 2020. Т. 29, экспрессвыпуск 1999. С. 5416-5421.

13. Титков А.С. Проблемы орнитологической безопасности аэропорта «Шереметьево» // Актуальные проблемы экологии и природопользования (вып. 5-6): системная экология: сб. науч. тр. / отв. ред. проф. Ю.П. Козлов. М.: Изд-во РУДН, 2004. С. 60-62.

14. Пронкевич В.В., Маннанов И.А. Эколого-орнитологическая обстановка аэродрома «Хабаровск» и прилегающей территории в 2009 г. // Вестник ДВО РАН. 2010. № 6. С. 52-59.

15. Борисов В.В., Урядова Л.П., Щеблыкина Л.С. Видовой состав и плотность населения птиц аэродрома города Пскова // Вестник Псковского государственного университета. Серия «Естественные и физико-математические науки». 2014. Вып. 5. С. 3-11. 
16. Соловьев С.А., Яковлев К.А. Население птиц на территории ОАО «Омский» аэропорт» в осенний период // Вестник Омского университета. 2014. № 2. С. 121124.

17. Носкова О.С., Колесова Н.Е., Баранов С.А. Сезонная и межгодовая динамика населения птиц Нижегородского международного аэропорта // Трансформация экосистем. 2020. Т. 3, № 2 (8). С. 94-110.

18. Доржиев Ц.З., Бадмаева Е.Н., Гулгенов А.З., Абашеев Р.Ю. Орнитологическая обстановка в районе аэропорта «Байкал» г. Улан-Удэ: условия обитания и население птиц в весенне-летний период // Вестник Бурятского государственного университета. Биология, география. 2016. Вып. 1. С. 51-69.

19. Сергеев С.В. Гнездящиеся птицы района аэропорта «Байкал» г. Улан-Удэ // Эволюция и современное состояние ландшафтов и биоты Внутренней Азии: мат-лы всерос. конф., посв. 75-летию со дня рожд. и 50-летию науч. и науч.-пед. деятельности профессора А.Б. Иметенова. Улан-Удэ: Изд-во ВСГТУ, 2016. С. 234-236.

20. Доржиев Ц.З., Бадмаева Е.Н., Елаев Э.Н., Гулгенов С.Ж., Сергеев С.В., Налетова Л.А. Сезонная динамика систематического разнообразия птиц аэропорта «Байкал» г. Улан-Удэ // Естественные и технические науки. 2019. № 1. С. 28-32.

21. Кузякин А.П. Зоогеография СССР // Ученые записки МОИП. Биогеография. 1962. Т. 109, вып. 1. С. 3-182.

22. Коблик Е.А., Редькин Я.А., Архипов В.Ю. Список птиц Российской Федерации. М.: Т-во науч. изд. КМК, 2006. 281 c.

23. Доржиев Ц.3. Птицы Бурятии и организация экологического туризма: учеб.-метод. пос. Улан-Удэ: Изд-во Бурятского госуниверситета, 2016. 80 с.

24. Садков В.С., Сафронов Н.Н. Материалы по структуре популяций и биологии чаек на Северном Байкале в устье Верхней Ангары // Экология наземных позвоночных Восточной Сибири. Иркутск, 1988. С. 29-44.

\begin{tabular}{|c|c|}
\hline Информация об авторе(-ах): & Information about the author(-s): \\
\hline $\begin{array}{l}\text { Бадмаева Евгения Николаевна, кандидат } \\
\text { биологических наук, доцент кафедры зоологии } \\
\text { и экологии; Бурятский государственный университет } \\
\text { им. Доржи Банзарова (г. Улан-Удэ, Российская } \\
\text { Федерация). E-mail: calidris03@gmail.com. }\end{array}$ & $\begin{array}{l}\text { Badmaeva Evgeniya Nikolaevna, candidate } \\
\text { of biological sciences, associate professor of Zoology } \\
\text { and Ecology Department; Buryat State University } \\
\text { named after D. Banzarov (Ulan-Ude, Russian } \\
\text { Federation). E-mail: calidris03@gmail.com. }\end{array}$ \\
\hline $\begin{array}{l}\text { Доржиев Цыдыпжап Заятуевич, доктор } \\
\text { биологических наук, профессор кафедры зоологии } \\
\text { и экологии; Бурятский государственный университет } \\
\text { им. Доржи Банзарова (г. Улан-Удэ, Российская } \\
\text { Федерация); ведущий научный сотрудник } \\
\text { лаборатории экологии и систематики животных; } \\
\text { Институт общей и экспериментальной биологии } \\
\text { СО РАН (г. Улан-Удэ, Российская Федерация). } \\
\text { E-mail: tsydypdor@mail.ru. }\end{array}$ & $\begin{array}{l}\text { Dorzhiev Tsydypzhap Zayatuevich, doctor of biological } \\
\text { sciences, professor of Zoology and Ecology Department; } \\
\text { Buryat State University named after D. Banzarov (Ulan- } \\
\text { Ude, Russian Federation); leading researcher of Ecology } \\
\text { and Systematics of Animals Laboratory; Institute } \\
\text { of General and Experimental Biology of the Siberian } \\
\text { Branch of the Russian Academy of Sciences (Ulan-Ude, } \\
\text { Russian Federation). E-mail: tsydypdor@mail.ru. }\end{array}$ \\
\hline $\begin{array}{l}\text { Сергеев Сергей Владимирович, старший } \\
\text { преподаватель кафедры промышленной экологии } \\
\text { и защиты в чрезвычайных ситуациях; Восточно- } \\
\text { Сибирский государственный университет технологий } \\
\text { и управления (г. Улан-Удэ, Российская Федерация). } \\
\text { E-mail: sv_sergeev@inbox.ru. }\end{array}$ & $\begin{array}{l}\text { Sergeev Sergey Vladimirovich, senior lecturer } \\
\text { of Industrial Ecology and Protection in Emergencies } \\
\text { Department; East Siberia State University of Technology } \\
\text { and Management (Ulan-Ude, Russian Federation). } \\
\text { E-mail: sv_sergeev@inbox.ru. }\end{array}$ \\
\hline $\begin{array}{l}\text { Гулгенов Сергей Жаргалович, кандидат } \\
\text { биологических наук, старший преподаватель } \\
\text { кафедры промышленной экологии и защиты } \\
\text { в чрезвычайных ситуациях; Восточно-Сибирский } \\
\text { государственный университет технологий } \\
\text { и управления (г. Улан-Удэ, Российская Федерация). } \\
\text { E-mail: gulgenov-s@mail.ru. }\end{array}$ & $\begin{array}{l}\text { Gulgenov Sergey Zhargalovich, candidate of biological } \\
\text { sciences, senior lecturer of Industrial Ecology } \\
\text { and Protection in Emergencies Department; East Siberia } \\
\text { State University of Technology and Management (Ulan- } \\
\text { Ude, Russian Federation). E-mail: gulgenov-s@mail.ru. }\end{array}$ \\
\hline $\begin{array}{l}\text { Максарова Дарима Дамбаевна, доктор } \\
\text { биологических наук, доцент кафедры зоологии } \\
\text { и экологии; Бурятский государственный университет } \\
\text { им. Доржи Банзарова (г. Улан-Удэ, Российская } \\
\text { Федерация). E-mail: d.maksarova@mail.ru. }\end{array}$ & $\begin{array}{l}\text { Maksarova Darima Dambaevna, doctor of biological } \\
\text { sciences, associate professor of Zoology and Ecology } \\
\text { Department; Buryat State University named after } \\
\text { D. Banzarov (Ulan-Ude, Russian Federation). } \\
\text { E-mail: d.maksarova@mail.ru. }\end{array}$ \\
\hline
\end{tabular}

\section{Для цитирования:}

Бадмаева Е.Н., Доржиев Ц.З., Сергеев С.В., Гулгенов С.Ж., Максарова Д.Д. Видовой состав и распределение птиц в аэропорту Нижнеангарск и на прилегающих территориях (Бурятия) // Самарский научный вестник. 2020. Т. 9, № 4. C. 15-22. DOI: 10.17816/snv202094102. 